\title{
The Empowerment Strategy of Newly Irrigated Rice Field Farmers through LEISA
}

\author{
Eries Dyah Mustikarini 1,* (D), and Ratna Santi ${ }^{1}$ \\ ${ }^{1}$ Department of Agrotechnology, Faculty of Agriculture, Fisheries, and Biology, \\ University of Bangka Belitung, 33172, Bangka Belitung Islands Province, Indonesia \\ * Corresponding Author: eriesdyah@yahoo.com
}

\section{ARTICLE INFO}

\section{Publication Info:}

Research Article

How to cite:

Mustikarini, E. D., E Santi, R. (2020). The Empowerment

Strategy of Newly Irrigated Rice

Field Farmers through LEISA.

Society, 8(1), 23-36.

DOI : 10.33019/society.v8i1.143

Copyright (C) 2020. Owned by Author(s), published by Society

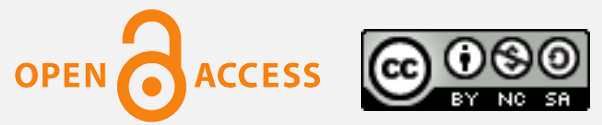

This is an open-access article.

\section{License: Attribution-}

NonCommercial-ShareAlike (CC BY-NC-SA)

Received: January 10, 2020; Accepted: February 24, 2020; Published: March 20, 2020;

\section{ABSTRACT}

Many newly irrigated rice field farmers in Bangka district leave their land empty. Farmers choose to do other farming activities or mining activities rather than rice cultivation. The area of newly irrigated rice fields in Bangka district is currently 2,200 hectares. The development of newly irrigated rice fields aims to increase rice production. The research aims: (1) Knowing the strengths, weaknesses, opportunities, and threats faced by farmers in the cultivation of rice in Kimak village, (2) Alternative strategies for community empowerment to increase farmers' incomes. The research was conducted in July-November 2019. The community empowerment strategy applied in this research is the application of the LEISA concept. The research was conducted using observational methods, interviews, and experiments. The respondents involved were 30 farmers. The research results showed that the application of the LEISA concept generated a profit of Rp 1,974,722 per three months, in an area of $1,680 \mathrm{~m}^{2}$. The implication, there is an increase in the number of farmers as many as 21 people who cultivate rice refers to the LEISA concept. 


\section{Introduction}

Rice farming community has an important role in development because almost all Indonesian people make rice as their staple food. Indonesia is a country that has not been able to meet its own food needs. Rice is still imported from Thailand and Vietnam. Since 2000, Indonesia has begun importing rice again and reached its peak in 2018 with a total import at 2.14 million tons (Badan Pusat Statistik, 2019). Low rice production is affected by a decline in community interest in farming.

Rice production is still not sufficient to meet people's food needs. The Ministry of Agriculture of the Republic of Indonesia recorded rice production in 2017 at 81.382 million tons, up 2.56\% compared to 2016 at 79.355 million tons (Kementerian Pertanian, 2019). The area of harvested land of rice in Bangka Belitung Islands Province is 8,618 hectares, milled dry rice production is 18,951 tons and rice is 11,176 tons (Badan Pusat Statistik Provinsi Kepulauan Bangka Belitung, 2018). Head of Food Crops and Horticulture, Agriculture Office of Bangka Belitung Islands Province said 81.5 percent of rice still relied on supplies from outside Bangka Belitung (Antara News Bangka Belitung, 2018).

Bangka Belitung Islands Province, according to the Assistant for Economy and Development of Bangka District, already had 2,200 hectares of rice fields in 2016 (Kompasiana, 2017). The rice field development program has been carried out since 2013, one of which was conducted in the Village of Kimak. The purpose of the rice field development program is done to increase rice production.

The total population of Kimak village is 3,198 people. 255 families in Kimak village are classified as poor families. The population of Kimak village who works as a farmer is 374 people. Irrigated rice field with an area of 281 hectares, but only 50 hectares are used (kimak.bangka.go.id, 2018). 231 hectares of irrigated rice fields were abandoned by villagers because of the maximum production of 2 tons/hectare.

With so much land left by farmers, it becomes an opportunity and challenge for the application of the LEISA technology package. This technology package is expected to increase the daily income of farmers so that rice fields do not become a side job. According to Astuti (2017), land in terms of quantity (land area) and quality (land fertility) plays an important role in increasing production and crop productivity. The problems in Kimak village will have an impact on the local food availability of the community.

The results of a previous study revealed that the farming community in the village of Kimak experienced a shortage of rice because it was not yet optimal in exploiting the potential of available rice fields. As many as $78.73 \%$ of the rice needs of the people of the Bangka Belitung Islands Province are still imported from outside areas (Bangka Pos, 2017). Kimak village farmers plant rice once a year and do not sell their crops and for their own consumption needs. The younger generation has not been active in rice cultivation activities. Potential water sources from village reservoirs have not been used optimally (Radar Bangka, 2018). Therefore it is necessary to do some efforts to overcome this matter such as education, and continuous assistance to farmers and the right strategy formulation is needed with a SWOT analysis (Strengths, Weaknesses, Opportunities, and Threats). Based on the existing problems, this research aims to carry out a community empowerment strategy by implementing the LEISA technology package to increase farmers' income in Kimak village. Knowing the strengths, weaknesses, opportunities, and threats faced by farmers in Kimak village in agricultural activities in the newly irrigated rice field. 


\section{Literature Review}

Farming communities, in general, are willing to cultivate plants if they see examples that have succeeded in doing so. Efforts to empower farmers must begin by giving examples. Farmers will follow successful methods for conducting crops. But this is also influenced by other factors. The characteristic which is significantly related to farmer's competence is formal education. In rural areas, where the average level of education in elementary school, setting an example to farmers is still appropriate (Manyamsari \& Mujiburrahmad, 2014).

Rice farmers in Kimak village feel that the monoculture system of rice cultivation has not been profitable. Farmers leave agricultural land not planted because the results are not able to meet the needs of the family.

Farming communities also need to be introduced to appropriate crop cultivation technology for acid soils. Farmers must realize that soils in Indonesia are diverse and that each type of soil requires proper treatment. Irrigated rice field in Kimak village is ultisol soil type. Ultisol soil type needs fertilization. According to Sitorus \& Soewandita (2010), the provision of 40 tons of ha-1 rice straw compost can increase crop production. According to Simamora et al., (2016), the provision of 2.5 tons of ha- 1 sheep manure can increase the exchangeability of cations, so that the fertilizer given is easily absorbed by plants. Farmers need to be introduced to methods of improving soil properties to increase soil fertility and crop production. Counseling and assistance to farmers need to be done continuously with the aim that farmers return to cultivate their irrigated rice fields.

Farmers who already have rice fields and are poor families need to be introduced to the Low External Input and Sustainable Agriculture (LEISA) technology package. The advantages of the LEISA system include that farmers only require low production inputs, increase the selling value of waste, get income every day, and preserve the environment. According to Setiyo et al., (2017), the implementation of the LEISA system can overcome the problems of food resilience and security, sustainable agriculture, and environmentally friendly agriculture. Franjaya et al., (2015) stated that the LEISA concept is following the demand of farmers in Karawang, West Java. Suwarto et al., (2015), stated the LEISA concept for spinach, kale, and chili, with beef cattle, laying ducks, as well as catfish and tilapia aquaculture provides quite high income to farmers in Riau. Yengoh \& Svensson (2008) stated that the implementation of the LEISA concept could provide a positive feedback effect on small scale agriculture in Kenya. Babou et al., (2009), showed the application of the LEISA concept to rice plants in India with the application of organic fertilizers provide higher yields and an increase in the organic content of $\mathrm{C}$, mineral $\mathrm{N}$, and total $\mathrm{N}$ in the soil. In other words, the implementation of LEISA concept is expected to be able to increase the income of the farmers of Kimak village.

The concept of empowerment is to increase the active role of the community. Tahrin et al., (2019) states that the steps of community empowerment according to the United Nations are as follows: (1) Knowing the characteristics of the local community, (2) Gathering information about the local community, (3) Identifying local leaders, (4) Providing an understanding of problems, (5) Helping to discuss problems, (6) Providing resolution to urgent problems, (7) Increasing community confidence, (8) Community programs need to be empowered to set programs appropriate for the local community, (9) Providing socialization of available resources, (10) Helping to solve problems, and (11) Increasing community independence.

\section{Research Methodology}

The research method used was a survey method and an experimental method. The survey method is done by using purposive sampling data collection techniques. Respondents 
determined were 30 people with the criteria of farmers aged 25-40 years and a minimum education of elementary school. The experimental method was carried out by making a LEISA mine project covering an area of $1,680 \mathrm{~m}^{2}$. Interviews were conducted with 30 respondents using a questionnaire containing questions related to strengths, weaknesses, opportunities, and threats faced when conducting rice cultivation in Kimak village. This research was conducted in July-November 2019. The research was located in Kimak village, Merawang sub-district, Bangka district, Bangka Belitung Islands Province, Indonesia. The results of the questionnaire were analyzed in the form of a SWOT analysis. Profit analysis to determine the potential implementation of LEISA, Rice-Fish-Duck (PERLABEK), in irrigated rice fields following the Pilot Project can be seen in Figure 1.

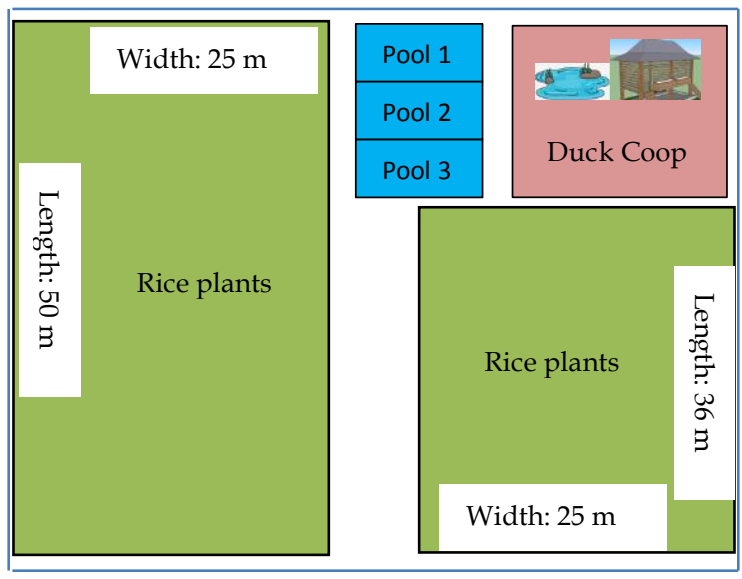

Figure 1. The layout of the Kimak village research pilot project, Merawang district

\section{Results and Discussion}

Kimak village has a large amount of irrigated rice fields, but it has not been optimally utilized by the local community due to the many challenges and obstacles faced by the community in rice cultivation. Based on the questionnaire, obtained data from Table 1 as follows:

Table 1. Questionnaire Results for Respondents (Farmers)

\begin{tabular}{|l|l|l|}
\hline Number & \multicolumn{1}{|c|}{ Question } & \multicolumn{1}{c|}{ Answer } \\
\hline $\mathbf{1 .}$ & $\begin{array}{l}\text { Potential of agricultural land in Kimak } \\
\text { village }\end{array}$ & Available 86.66\%; not available 13.33\% \\
\hline $\mathbf{2 .}$ & The level of activity of farmer groups & $\begin{array}{l}\text { Active 16.66\%; moderate 43.33\%; and low } \\
40.00 \%\end{array}$ \\
\hline $\mathbf{3 .}$ & Agricultural income & Rp 3,291,666.67 \\
\hline $\mathbf{4 .}$ & Availability of rice seeds & Available 93.33\%; not available 6.66\% \\
\hline $\mathbf{5 .}$ & Rice field area & 0.65 Hectares \\
\hline $\mathbf{6 .}$ & Agricultural land managed in a year & $\begin{array}{l}\text { Once per year: 63.33\%, } \\
\text { Twice a year: 30\%, } \\
\text { Three times a year: 6.66\% }\end{array}$ \\
\hline $\mathbf{7 .}$ & Types of Agricultural Water Use & $\begin{array}{l}\text { Rain-fed rice field: } 20 \%, \\
\text { Open ditch irrigation: } 6.66 \%, \\
\text { Open-close irrigation: 73.33\% }\end{array}$ \\
\hline
\end{tabular}

Copyright ( $(2020$. Owned by Author(s), published by Society. This is an open-access article under the CC-BY-NC-SA license. https://doi.org/10.33019/society.v8i1.143 
The Empowerment Strategy of Newly Irrigated Rice Field Farmers through LEISA

\begin{tabular}{|c|c|c|}
\hline Number & Question & Answer \\
\hline 8. & Irrigation water availability & Available $66.66 \%$; not available $33.33 \%$ \\
\hline 9. & $\begin{array}{l}\text { Farmers get rice seeds from the } \\
\text { government }\end{array}$ & Available $100 \%$ \\
\hline 10. & Amount of seed aids & $9.06 \mathrm{Kg}$ \\
\hline 11. & $\begin{array}{l}\text { Types of rice plants that are suitable on } \\
\text { the farmland of Kimak village }\end{array}$ & Varieties $96.66 \%$; accessions $3.33 \%$ \\
\hline 12. & $\begin{array}{l}\text { The amount of production obtained by } \\
\text { farmers }\end{array}$ & 0.6 Ton/hectare \\
\hline 13. & Availability of agricultural equipment & $\begin{array}{l}\text { Hand tractor } 100 \% \text {; planting machines } \\
0 \% \text {; rice-growing machines } 100 \% \text {; rice } \\
\text { thresher machine } 100 \% \text {; rice dryer } 10 \% \text {; } \\
\text { rice husk } 100 \%\end{array}$ \\
\hline 14. & Availability of rice thresher tools & Available $100 \%$; not available $0 \%$ \\
\hline 15. & Cost of managing rice fields & $\operatorname{Rp} 4,156,666.67$ \\
\hline 16. & $\begin{array}{l}\text { Purchase costs for organic and } \\
\text { inorganic fertilizers }\end{array}$ & $\operatorname{Rp} 1,121,666.67$ \\
\hline 17. & $\begin{array}{l}\text { Ease of getting organic and inorganic } \\
\text { fertilizers }\end{array}$ & Easy $90 \%$; difficult $10 \%$ \\
\hline 18. & $\begin{array}{l}\text { The target market for agricultural } \\
\text { product sales }\end{array}$ & Collector $20 \%$; consumer $80 \%$ \\
\hline 19. & Price of rice produced & $\begin{array}{l}\text { Brown rice: } \operatorname{Rp} 15,000.00 \text {, } \\
\text { White rice: } \operatorname{Rp} .13,000.00\end{array}$ \\
\hline 20. & Benefits of rice farmers & $\operatorname{Rp~3,003,333.33}$ \\
\hline 21. & Other jobs & Yes $83.33 \%$; no $16,66 \%$ \\
\hline 22. & Average income from other jobs & Rp 3,752,333.33 \\
\hline 23. & $\begin{array}{l}\text { Land suitability available for rice } \\
\text { plants }\end{array}$ & Available $96.66 \%$; not available $3.33 \%$ \\
\hline 24. & $\begin{array}{l}\text { Community interest in buying rice } \\
\text { products }\end{array}$ & Interested $100 \%$ \\
\hline 25. & $\begin{array}{l}\text { The price of rice is more expensive } \\
\text { than the price of rice sold in stores }\end{array}$ & Agree $76.66 \%$, disagree $23,33 \%$ \\
\hline 26. & $\begin{array}{l}\text { Availability of information media or } \\
\text { promotion of agricultural products }\end{array}$ & Available $13.33 \%$; not available $86.66 \%$ \\
\hline 27. & Agricultural product sales distribution & $\begin{array}{l}\text { Distributed } 76.66 \% \text {; not distributed } \\
23.33 \%\end{array}$ \\
\hline 28. & Market demand & High $63.33 \%$; moderate $33.33 \%$; low. $3.33 \%$ \\
\hline 29. & $\begin{array}{l}\text { Distribution of fertilizer to Kimak } \\
\text { village }\end{array}$ & Distributed $96.66 \%$ \\
\hline 30. & Rice Pests & 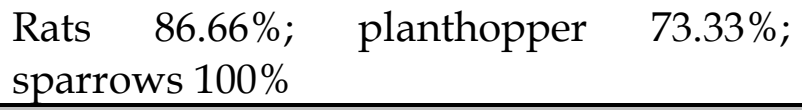 \\
\hline 31. & Pest Control & Trap $80 \%$; pesticides $76.66 \%$; other $23.33 \%$ \\
\hline 32. & Losses due to pests & $\operatorname{Rp} 2,241,666.67$ \\
\hline 33. & Rice plant diseases & Blast disease $86.66 \%$; other $33.33 \%$ \\
\hline 34. & Overcoming plant diseases & Pesticides 33.33\% \\
\hline
\end{tabular}

Copyright ( $(2020$. Owned by Author(s), published by Society. This is an open-access article under the CC-BY-NC-SA license. https://doi.org/10.33019/society.v8i1.143 


\begin{tabular}{|l|l|l|}
\hline Number & \multicolumn{1}{|c|}{ Question } & \multicolumn{1}{c|}{ Answer } \\
\hline 35. & Losses due to plant diseases & $\operatorname{Rp~2,241,666.67~}$ \\
\hline 36. & Interest in managing rice fields & Interested $46.66 \%$; not interested $53.34 \%$. \\
\hline
\end{tabular}

The people of Kimak village who manage rice fields are over 30 years old. On average, they manage rice fields for less than 8 years, with an area of $0.25-1.00$ hectares. Community income from agricultural products is around $\mathrm{Rp} 3,000,000.00$. Rice seeds are available and seeds are also received from government aids of about $5-20 \mathrm{~kg}$. The appropriate type of rice in the Kimak village is rice varieties. Irrigation systems for rice fields in Kimak village are available, but the existing irrigation water is acidic, so it is not good for growing rice. The irrigation system used in the village of Kimak is open-close irrigation (Table 1).

The average amount of rice produced by the community is 0.6 tons/ha. Agricultural equipment in Kimak village is sufficient but the Farmers Group Association (Gabungan Kelompok Tani or Gapoktan) in Kimak village is not very active. Costs incurred by farmers to manage their fields on average are $\operatorname{Rp~4,000,000~and~fertilizer~Rp~1,000,000.~Fertilizer~distribution~to~Kimak~}$ village is quite adequate. Farmers sell their crops to consumers directly without intermediary traders. The price of brown rice is $\mathrm{Rp} 15,000 / \mathrm{kg}$ while the white rice is $\mathrm{Rp} 13,000 / \mathrm{kg}$. This price is the same as the price sold in the store. Some farmers do not sell their crops. In other words, the harvest is used for daily needs. Media information for the promotion of agricultural products is not yet available but the distribution of product sales is quite good and the market demand for products is high. The profits from rice production range from Rp. $0-20,000,000$. The land in Kimak village is suitable for rice cultivation. Pests and diseases that often attack rice plants in the village of Kimak are pests (sparrows, rats and plant hopper) and diseases (blast and yellow disease). Farmers deal with pests and diseases as follows 1) pests (using traps, others use nets and salt); 2) disease (using pesticides). Farmer losses due to pests and diseases are Rp. 2,000,000 on average (Table 1).

On average, farmers in the village of Kimak are not interested in managing rice fields. Problems faced by farmers are losses due to pests, acid water, the ability to adopt technology, the level of education, and the availability of capital in each period. The type of soil in Kimak village is ultisol soil type. Ultisol soil is a type of soil that has many problems related to soil fertility. Ultisol soils generally have a low $\mathrm{pH}$ which causes high dissolved $\mathrm{Al}, \mathrm{Fe}$, and $\mathrm{Mn}$ content. This can poison plants, so treatment is needed to increase soil fertility. According to Sitorus et al., (2014), aluminum can inhibit plant growth and productivity because it contains rhizotoxic ions. Another obstacle is the availability of water in the dry season. According to Yulia et al., (2018), the availability of less irrigation water in the dry season causes a decrease in production. Water availability will affect nutrient dissolution from fertilizers and minerals as well as translocation to root areas. This condition will encourage physiological and metabolic processes, thus encouraging the growth of the upper part of the plant (canopy), in this case, the maximum number of tillers and the number of productive tillers. SWOT analysis is used in this study to assess Strengths (S); Weakness (W); Opportunities (O), and Threats (T) to variables: (1) physical such as regional morphology and hydrometeorology; (2) socio-economic and institutions such as population, land status, infrastructure, and marketing support, and institutions at the farm level; and (3) government support and policies such as regulations and financial support. Based on the analysis results, the following data are obtained: 
Table 2. SWOT analysis for farmers in Kimak village

\begin{tabular}{|c|c|c|c|}
\hline \multirow{2}{*}{\multicolumn{2}{|c|}{ EXTERNAL FACTORS }} & OPPORTUNITIES (O) & THREATS (T) \\
\hline & & $\begin{array}{l}\text { 1. Increasing needs for rice } \\
\text { 2. Increase in population } \\
\text { 3. The development of } \\
\text { information technology, } \\
\text { mechanization, and new } \\
\text { superior varieties } \\
\text { 4. The development of } \\
\text { food products derived } \\
\text { from rice } \\
\text { 5. Availability of banking } \\
\text { as a source of funds } \\
\text { 6. The existence of } \\
\text { agricultural insurance }\end{array}$ & $\begin{array}{l}\text { 1. The price of rice from outside } \\
\text { the village is cheaper } \\
\text { 2. An increase in prices of } \\
\text { agricultural inputs } \\
\text { continuously } \\
\text { 3. Increased production costs } \\
\text { 4. Bank loans that require } \\
\text { collateral } \\
\text { 5. Climate change } \\
\text { 6. Government regulations that } \\
\text { set Harga Eceran Tertinggi } \\
\text { (Price Highest Retail) of rice } \\
\text { production } \\
\text { 7. Pests that are resistant to } \\
\text { pesticides }\end{array}$ \\
\hline $\begin{array}{c}S \\
T \\
R \\
E \\
N \\
G \\
T \\
\mathbf{H} \\
\text { (S) }\end{array}$ & $\begin{array}{l}\text { 1. The area of rice } \\
\text { fields is } 281 \\
\text { hectares } \\
\text { 2. Most rice fields are } \\
\text { owned by farmers } \\
\text { 3. Rice farming is a } \\
\text { family business that } \\
\text { has been carried } \\
\text { down for } \\
\text { generations } \\
\text { 4he average } \\
\text { experience of } \\
\text { farming is quite } \\
\text { long } \\
\text { 5. Farmers have other } \\
\text { income outside of } \\
\text { rice farming } \\
\text { 6. Farmers are already } \\
\text { incorporated into } \\
\text { farmer groups, } \\
\text { making it easier to } \\
\text { access assistance }\end{array}$ & $\begin{array}{l}\text { 1. Cooperation between } \\
\text { farmers and farmer } \\
\text { groups in crop } \\
\text { cultivation to eradicate } \\
\text { pests and plant diseases } \\
\text { 2. Implement financing } \\
\text { management by a } \\
\text { particular agency or } \\
\text { organization } \\
\text { 3. Increasing production } \\
\text { and productivity } \\
\text { through the } \\
\text { implementation of new } \\
\text { technologies and new } \\
\text { superior varieties }\end{array}$ & $\begin{array}{l}\text { 1. Make optimal use of } \\
\text { production facilities and } \\
\text { infrastructure provided by the } \\
\text { government } \\
\text { 2. Conducting integrated } \\
\text { farming through the } \\
\text { implementation of LEISA or } \\
\text { polyculture } \\
\text { 3. Implement an efficient } \\
\text { farming system } \\
\text { 4. Conduct counseling to deal } \\
\text { with climate change in the rice } \\
\text { farming sector }\end{array}$ \\
\hline
\end{tabular}

Copyright ( $(2020$. Owned by Author(s), published by Society. This is an open-access article under the CC-BY-NC-SA license. https://doi.org/10.33019/society.v8i1.143 


\begin{tabular}{|c|c|c|c|}
\hline $\begin{array}{c}\text { W } \\
\text { E } \\
\text { A } \\
\text { K } \\
\mathbf{N} \\
\text { E } \\
S \\
\text { S } \\
(\mathbf{W})\end{array}$ & $\begin{array}{l}\text { 1. The emergence of } \\
\text { plant-disturbing } \\
\text { organisms (PDOs) } \\
\text { 2. Planting activities } \\
\text { are not } \\
\text { simultaneous with } \\
\text { other farmers } \\
\text { 3. Farmers still } \\
\text { consider rice } \\
\text { farming as a side } \\
\text { job } \\
\text { 4. The farm area is } \\
\text { relatively small } \\
\text { 5. The average farmer } \\
\text { education level is } \\
\text { low } \\
\text { 6. Lack of agricultural } \\
\text { extension workers, } \\
\text { especially about } \\
\text { pests and diseases } \\
\text { 7. Farmers do not } \\
\text { have a certain } \\
\text { farming budget at } \\
\text { the beginning of } \\
\text { each period } \\
\text { 8. Irrigation water } \\
\text { does not reach } \\
\text { farmland } \\
\text { 9. The young } \\
\text { generation is not } \\
\text { interested in doing } \\
\text { rice farming }\end{array}$ & $\begin{array}{l}\text { 1. Intensive and } \\
\text { integrated control of } \\
\text { PDOs } \\
\text { 2. Farmers maintain the } \\
\text { cohesiveness of } \\
\text { planting time to reduce } \\
\text { PDOs } \\
\text { 3. Making trials for } \\
\text { technology adaptation } \\
\text { and superior varieties, } \\
\text { for each region } \\
\text { 4. Utilization of various } \\
\text { agricultural wastes to } \\
\text { support further } \\
\text { cultivation } \\
\text { (composting) } \\
\text { 5. Provide incentives for } \\
\text { youth, who want to } \\
\text { manage rice farming }\end{array}$ & $\begin{array}{l}\text { 1. Increasing farmers' knowledge } \\
\text { and skills by carrying out } \\
\text { activities; counseling, training, } \\
\text { and mentoring with the aim } \\
\text { that farmers can produce } \\
\text { competitive products } \\
\text { 2. Implement the LEISA system } \\
\text { to fertilize the soil and } \\
\text { produce healthy products } \\
\text { 3. Use of superior seeds that are } \\
\text { resistant to drought and } \\
\text { climate change } \\
\text { 4. Increase agricultural extension } \\
\text { workers, especially about pest } \\
\text { and disease control } \\
\text { 5. Utilization of village reservoir } \\
\text { water in the dry season by } \\
\text { using a water suction machine }\end{array}$ \\
\hline
\end{tabular}

Based on the results of the SWOT analysis (Table 2), the way to overcome this problem is by conducting counseling and assistance to rice farmers about agricultural land management and good rice cultivation practices. Most of the problems in increasing crop yields are caused by the inappropriate implementation of technology. The success of increasing rice production and productivity needs to be disseminated to farmers through counseling and assistance. Counseling is expected to change the knowledge, attitudes, and behavior of farmers and their families in conducting farming, from traditional farming patterns and not yet implementing good and right agricultural technology towards effective agriculture. Farmers are expected to make tangible changes in terms of improving production, improving the quality of rice grain, and implementing innovations or new technologies of continuous cultivation of rice. The success of the community empowerment program, according to Shamadiyah (2017), needs to be directed to change the mindset of the community. According to Swastika et al., (2007) based on the results of a SWOT analysis conducted that an increase in rice production is compensation from land conversion. So that community empowerment measures in the village of Kimak 
require efforts to synergize with the village government and the agriculture office. The community needs to adopt advanced technology prepared by the government to increase rice production.

Tabel 3. The results of the analysis of farming with the LEISA technology package

A. Rice Farming

1. Fixed Cost

Cost of depreciation

187,083

Total Fixed Costs

187.083

2. Variable Cost

a. Production Facilities

1. Seed

250,000

2. Organic fertilizer

900,000

3. Urea (fertilizer)

200,000

4. NPK 88 (fertilizer)

200,000

5. Pesticide Furadan

23,000

6. Pesticide Reagan

31,000

7. Pesticide Gramoxone

210,000

8. Pesticide Regent

50,000

b. Worker

Total Variable Cost

Total Cost of Rice Farming

\section{B. Laying Duck Cultivation}

1. Fixed Cost

Cost of depreciation

Total Fixed Costs

2. Variable Cost

a. Production Facilities

1. Livestock seedlings (3 months)

2. Concentrate

3. Vitamin

4. Fine bran

b. Worker

Total Variable Cost 
C. Catfish Cultivation

\section{Fixed Cost}

Cost of depreciation

122,354

Total Fixed Costs

2. Variable Cost

a. Production Facilities

1. Seed

$1,200,000$

2. Fish feed

$2,000,000$

3. Catfish Vitamins

32,000

b. Worker

Total Variable Cost

Total Cost of Catfish Cultivation

$3,754,354$

Total Fixed Cost of LEISA Farming

\section{Revenue Component \\ A. Rice Farming \\ B. Laying Duck Cultivation \\ C. Catfish Cultivation \\ Total Revenue Components}

The amount of costs (Rp)

$2,993,760$

$2,760,000$

$4,301,000$

$10,056,000$

The LEISA technology package by combining rice, catfish and duck cultivation (PERLABEK) shows that the cost of farming (fixed and variable costs) is lower than the selling price of the product. The results of the analysis of farming with the LEISA technology package show that the income received by farmers is $\mathrm{Rp} 1,974,722$ per 3 month in an area of 1,680 $\mathrm{m}^{2}$ (Table 3). Total income if calculated in 1 hectare per 3 months, farmers will get an income of Rp $11,754,297.62$ per 3 months. This high profit is expected to encourage the farming community to develop rice fields.

This community empowerment program needs an active role in the community. According to Soegiharto et al., (2019), community empowerment is an effort or process of exploring and utilizing the potentials of the community to meet their needs as the application of the principle of helping the community to help themselves can become a reality. According to Noor (2011), three main efforts in community empowerment are: 1) creating conditions that enable the potential of developing communities (enabling), 2) strengthening the potential of the community (empowering), and 3) protecting and defending the interests of the lower classes (protecting), seems to be 3 (three) main pillars of community empowerment as a model of community-based development.

Empowerment is carried out with the help of agricultural extension workers and the village government. After the community empowerment activities were carried out, the Kimak village farmers began to reuse their potential, such as managing agricultural land that had been left. 
The Kimak village government in collaboration with the Farmers Group Association provides loans for equipment needed by farmers such as rice thresher machines, hand tractors, rice husk peeling machines, and rice drying machines. According to Kessler \& Moolhuijzen (1994), the success of LEISA must be adjusted to the ecology of the environment and the ability of the community. Djuwendah et al., (2018) added that the use of local resources in implementing LEISA can reduce dependence on external resources and support sustainable food security. The potential of Kimak village farmers such as the availability of agricultural land, irrigation systems, seeds, fertilizers, and agricultural tools which are aids from the government need to be utilized optimally. In the future, this community empowerment program is expected to increase the income of Kimak village farmers by using alternative LEISA technology packages. Community empowerment with the concept of LEISA is effective because, after empowerment activities, there are 21 farmers recorded that they cultivate their agricultural land again and do crop cultivation.

\section{Conclusions}

The internal problem of Kimak village farmers in the cultivation of rice plants in the newly irrigated rice fields is the lack of ability to overcome the attack of plant-disturbing organisms such as birds, plant hopper and blast disease. The external problem of Kimak village farmers is the presence of imported rice which has lower selling prices with better quality so that their rice products are less attractive to consumers. The results of implementing the LEISA technology package by combining rice cultivation, catfish, and laying ducks (PERLABEK) obtained a profit of Rp 1,974,722 per 3 months, in an area of 1,680 $\mathrm{m}^{2}$. Through this community empowerment program, there are currently 21 Kimak village farmers who cultivate rice after learning the benefits.

\section{Acknowledgment}

The authors would like to thank the Ministry of Research, Technology and Higher Education of the Republic of Indonesia for support and facilities for making this research success through Student Community Service - Community Empowerment Learning Grant Scheme Program (Kuliah Kerja Nyata - Pembelajaran Pemberdayaan Masyarakat or KKN-PPM), Decree Number 8/E/KPT/2019. The authors also wish to thank the Institute for Research and Community Services of the University of Bangka Belitung for support and facilities during this program and research conducted.

\section{References}

Antara News Bangka Belitung. (2018, 11 5). BPS: Produksi padi petani Bangka Belitung 11.619 ton. Retrieved from babel.antaranews.com: https://babel.antaranews.com/berita/88202/bpsproduksi-padi-petani-bangka-belitung-11619-ton

Astuti, A. (2017). Analisis Produksi Dan Pendapatan Usahatani Padi Sawah Metode System Of Rice Intensification Di Kecamatan Sindue Kabupaten Donggala. Mitra Sains, 5(1), 36-42. http://jurnal.untad.ac.id/jurnal/index.php/MitraSains/article/view/7684

Babou, C., Poyyamoli, G., \& Guna, B. (2009). Impact of LEISA based system of rice intensification (SRI) practices on rice grain yield and soil properties in rice-rice-rice cropping system in Puducherry region. International Journal of Agricultural Sciences, 5(1), 43-45. https:/ / www.cabdirect.org/cabdirect/abstract/20093099107 
Bangka Pos. (2017, 12 21). Panen Padi Bersama: Swasembada Beras Dimantapkan. Retrieved 2 24, 2020, from bangka.tribunnews.com: https://bangka.tribunnews.com/2017/12/21/panenpadi-bersama-swasembada-beras-dimantapkan

Badan Pusat Statistik. (2019). Impor Beras Menurut Negara Asal Utama, 2000-2008. Retrieved from bps.go.id: https://www.bps.go.id/statictable/2014/09/08/1043/impor-beras-menurutnegara-asal-utama-2000-2018.html

Badan Pusat Statistik Provinsi Kepulauan Bangka Belitung. (2018). Luas Panen Bangka Belitung selama Januari-Desember 2018 sebesar 8.618 hektar dan produksi padi sebesar 18.951 ton GKG. Retrieved from babel.bps.go.id: https:// babel.bps.go.id/pressrelease/2018/11/01/587/luas-panen-bangka-belitungselama-januari-desember-2018-sebesar--8-618-hektar-dan-produksi-padi-sebesar-18-951ton-gkg-.html

Djuwendah, E., Priyatna, T., Kusno, K., Deliana, Y., \& Wulandari, E. (2018). Building agribusiness model of LEISA to achieve sustainable agriculture in Surian Subdistrict of Sumedang Regency West Java Indonesia. In IOP Conference Series: Earth and Environmental Science (Vol. 142). Institute of Physics Publishing. https://doi.org/10.1088/1755$1315 / 142 / 1 / 012062$

Franjaya, E. E., Gunawan, A., \& Mugnisjah, W. Q. (2015). Application of Sustainable Agriculture based on LEISA in Landscape Design of Integrated Farming. In The 7th International Conference on Sustainable Agriculture for Food, Energy, and Industry in Regional and Global Context, (Vol. 7). Retrieved from https://www.researchgate.net/publication/315824046_Application_of_Sustainable_Agric ulture_based_on_LEISA_in_Landscape_Design_of_Integrated_Farming

Kementerian Pertanian. (2019). Laporan Kinerja Pusat Penelitian dan Pengembangan Tanaman Pangan 2018. Bogor: Pusat Penelitian dan Pengembangan Tanaman Pangan, Badan Penelitian dan Pengembangan Pertanian, Kementerian Pertanian. Retrieved from http:/ / pangan.litbang.pertanian.go.id/files/lakip/lakip2018.pdf

Kessler, J. J., \& Moolhuijzen, M. (1994). Low external input sustainable agriculture: expectations and realities. Netherlands Journal of Agricultural Science, 42(3), 181-194. https://library.wur.nl/ojs/index.php/njas/article/view/596

Kimak.bangka.go.id. (2018). Data Umum Desa. Retrieved from kimak.bangka.go.id: http://kimak.bangka.go.id/content/data-umum-desa

Kompasiana. (2017, 9 7). Kabupaten Bangka Punya Potensi Lahan Sawah 4.410 Hektar. Retrieved 12 2, 2019, from kompasiana.com: https://www.kompasiana.com/eddo.richardo/59b0eec77aafb21dfe3d9bc2/kabupatenbangka-punya-potensi-lahan-sawah-4-410-hektar

Manyamsari, I., \& Mujiburrahmad, M. (2014). Karakteristik Petani Dan Hubungannya Dengan Kompetensi Petani Lahan Sempit (Kasus: Di Desa Sinar Sari Kecamatan Dramaga Kab. Bogor Jawa Barat). Jurnal Agrisep, 15(2), 58-74. http://www.jurnal.unsyiah.ac.id/agrisep/article/view/2099

Noor, M. (2011). Pemberdayaan Masyarakat. CIVIS, 1(2), 87-99. http://journal.upgris.ac.id/index.php/civis/article/view/591

Radar Bangka. (2018, 1 26). Petani Pilih Konsumsi Beras Sendiri. Retrieved 2 24, 2020, from radarbangka.co.id:

https://www.radarbangka.co.id/berita/detail/sungailiat/48879/petani-pilih-konsumsiberas-produksi-sendiri 
Setiyo, Y., Gunadnya, I. B. P., Gunam, I. B. W., \& Susrusa, I. K. B. (2017). The implementation of low external input sustainable agriculture system to increase productivity of potato (Solanum tuberosum L.). Journal of Food, Agriculture and Environment, 15(2), 62-67. https:/ / www.wflpublisher.com/Abstract/1118

Shamadiyah, N. (2017). Analisis Swot Strategi Pemberdayaan Masyarakat Program Penataan Lingkungan Permukiman Komunitas Di Kelurahan Suryatmajan, Kota Yogyakarta. Agrifo: Jurnal Agribisnis Universitas Malikussaleh, 2(1), 28. https://doi.org/10.29103/ag.v2i1.506

Simamora, A. J., Rauf, A., Marpaung, P., \& Jamila, J. (2016). Perbaikan Sifat Kimia Tanah Sawah Akibat Pemberian Bahan Organik Pada Pertanaman Semangka (Citrullus Lanatus). Jurnal Agroekoteknologi, $4(4)$,

2196-2201.

https://jurnal.usu.ac.id/index.php/agroekoteknologi/article/view/13417

Sitorus, S., \& Soewandita, H. (2010). Rehabilitation of Degraded Land using Paddy Straw Compost and Peat for Agriculture Purposes. Jurnal Tanah Dan Iklim, 31(1), 27-37. http://www.ejurnal.litbang.pertanian.go.id/index.php/jti/article/view/214

Sitorus, H. L., Marulak, S., \& Bilman, W. (2014). Respon Beberapa Kultivar Padi Gogo pada Ultisol Terhadap Pemberian Aluminium dengan Konsentrasi Berbeda (Doctoral dissertation, Universitas Bengkulu). Retrieved from http://repository.unib.ac.id/10392/

Soegiharto, S., Purbandini, L., Ariyanto, N., Yustina, F., Purbantara, A., \& Hayati, H. (2019). Model Kuliah Kerja Nyata (KKN) Tematik Desa Membangun. Cetakan Pertama. Jakarta: Kementerian Desa Pembangunan Daerah Tertinggal dan Transmigrasi. Retrieved from https://balilatfo.kemendesa.go.id/index.php/publikasi/getdata/Model_KKN_Tematik_ Desa_Membangun.pdf

Suwarto, S., Aryanto, A. T., \& Effendi, I. (2015). Perancangan Model Pertanian Terpadu Tanaman-Ternak dan Tanaman-Ikan di Perkampungan Teknologi Telo, Riau. Jurnal Agronomi Indonesia (Indonesian Journal of Agronomy), 43(2), 168-178. https://journal.ipb.ac.id/index.php/jurnalagronomi/article/view/10424

Swastika, D. K., Wargiono, J., Soejitno, S., \& Hasanuddin, A. (2007). Analisis Kebijakan Peningkatan Produksi Padi melalui Efisiensi Pemanfaatan Lahan Sawah di Indonesia. Analisis Kebijakan Pertanian, 36-52. http://www.ejurnal.litbang.pertanian.go.id/index.php/akp/article/view/4369

Tahrin, N., Rares, J., \& Tampongangoy, D. (2019). Pemberdayaan Masyarakat Desa Malawor Distrik Makbon Kabupaten Sorong (Studi Tentang Program Percetakan Sawah). Jurnal Administrasi Publik, 5(77), $1-11$. https://ejournal.unsrat.ac.id/index.php/JAP/article/download/23807/23457

Yengoh, G. T., \& Svensson, M. G. E. (2008). Low external input strategies for sustainable smallscale farming in Kenya: A systems Dynamic Approach. In 26th International Conference of the System Dynamics Society (pp. 20-24). https:// proceedings.systemdynamics.org/2008/proceed/papers/GENES392.pdf

Yulia, R., Nelvia, N., \& Ariani, E. (2018). Pengaruh campuran cocopeat dan rock phosphate terhadap pertumbuhan dan hasil tiga varietas padi gogo (oryza sativa 1.) pada medium ultisol. Jurnal Solum, 15(1), 17-25. https:/ / doi.org/10.25077/jsolum.15.1.17-25.2018 
About the Authors

1. Eries Dyah Mustikarini, obtained her Doctoral of Agricultural Sciences in Plant Breeding and Biotechnology from Brawijaya University, Malang, Indonesia, in 2016. The author is an assistant professor at the Department of Agrotechnology, Faculty of Agriculture, Fisheries, and Biology, University of Bangka Belitung, Indonesia.

E-Mail: eriesdyah@yahoo.com

2. Ratna Santi, obtained her Doctoral of Agricultural Sciences in Soil Biotechnology from Padjadjaran University, Bandung, Indonesia. The author is an assistant professor at the Department of Agrotechnology, Faculty of Agriculture, Fisheries, and Biology, University of Bangka Belitung, Indonesia.

E-Mail: ratnasanti_ubb@yahoo.com 